\title{
ELECTROPHYSIOLOGICAL EFFECTS OF VALSALVA MANOEUVER DURING EARLY PREGNANCY IN PATIENTS WITH PAROXYSMS OF ORTHODROMIC ATRIOVENTRICULAR TACHYCARDIA
}

\author{
FAGIM KASYMOVICH RAKHMATULLOV*, ALSU MUZAFYAROVNA KURYAEVA, INESSA JAKOVLEVNA MOISEEVA, \\ LARISA FEDOROVNA BURMISTROVA, NIKITA EVGEN'EVICH DYATLOV
}

Department of Internal Diseases, Medical Institute, Penza State University, Ministry of Education and Science of the Russian Federation, 440026 Penza, Russia. Email: moiseeva_pharm@mail.com

Received: 31 March 2017, Revised and Accepted: 25 April 2017

ABSTRACT

Objective: The aim is to study electrophysiological (EPh) indicators of the heart in pregnant women in the first trimester with orthodrome paroxysms of reciprocal atrioventricular tachycardia during the Valsalva test, after a single dose of propafenone and a combination of Valsalva test with propafenone.

Methods: Clinical survey, assessment of medical history, physical examination, electrocardiogram (ECG) in 12 leads, Holter ECG monitoring, echocardiography, expert ultrasound examination of the fetus, transesophageal EPh study of the heart, the blood test for electrolytes (potassium, sodium), thyroid hormones $\left(\mathrm{T}_{3}, \mathrm{~T}_{4}\right.$, thyroid-stimulating hormone) were included in this study. We examined 28 women during an early gestation.

Results: We found that the Valsalva manoeuver, Propanorm, and the combination of the Valsalva manoeuver and Propanorm produced an antiarrhythmic effect through the anterograde and retrograde conduction in reentry.

Discussion: The study is the first to reveal that the Valsalva manoeuver influences retrograde conduction in reentry in pregnant patients.

Conclusion: We proved that it is necessary to use the Valsalva manoeuver to stop paroxysms of orthodromic atrioventricular tachycardia (POAVRT) in the first trimester of pregnancy. If the manoeuver is ineffective, it is advisable to use Propanorm or combination of Propanorm with Valsalva manoeuver.

Keywords: Orthodromic atrioventricular reentrant tachycardia paroxysms, Pregnancy, Valsalva manoeuver, Propanorm.

(C) 2017 The Authors. Published by Innovare Academic Sciences Pvt Ltd. This is an open access article under the CC BY license (http://creativecommons. org/licenses/by/4. 0/) DOI: http://dx.doi.org/10.22159/ajpcr.2017.v10i8.18827

\section{INTRODUCTION}

During the paroxysms of reciprocal atrioventricular (AV) orthodrome tachycardia, the circulation of impulse occurs for the first in the anterograde direction - from the atria to the ventricles through the normal conduction system of the heart and then it goes retrogrades, from ventricles to the atria, in an abnormal way [1-5].

In previous studies [6-9], we have found that in women with POAVRT in the early stages of a gestation, there is the shortening of the effective refractory period (ERP) of the AV node, the upper window and the lower window of tachycardia, expanding the zone of tachycardia, the dispersion of refractory period of $\mathrm{AV}$ connection, and a retrograde pathway. These electrophysiological (EPh) changes indicate a high arrhythmogenic readiness of the heart.

The purpose was to study EPh indicators of the heart in pregnant women in the first trimester with orthodrome paroxysms of reciprocal $\mathrm{AV}$ tachycardia during the Valsalva test, after a single dose of propafenone and a combination of Valsalva test with propafenone.

\section{METHODS}

A clinical study was conducted in the period from 2013 to 2015 at the SBMH “Clinical Hospital No. 6 named after G. A. Zakharyin" in Penza.

There were examined 28 pregnant women with paroxysms of POAVRT, age from 19 to 32 years $(26.5 \pm 2.5)$.

Studies included Clinical survey, assessment of medical history, physical examination, electrocardiogram (ECG) in 12 leads, Holter ECG monitoring, echocardiography, expert ultrasound examination of the fetus, transesophageal EPh study of the heart, the blood test for electrolytes (potassium, sodium), and thyroid hormones $\left(\mathrm{T}_{3}, \mathrm{~T}_{4}\right.$, thyroid-stimulating hormone). Variation statistics and correlation analysis were performed using the software package Microsoft Excel 7.0 and Statistica 6.0. For a dynamic control, the results of the studies were used Holter monitoring of ECG and transesophageal electrical stimulation.

All patients included in the study who signed written consent.

\section{RESULTS AND DISCUSSION}

Table 1 shows ECG and EPh indicators of the heart during the first Valsalva test, after a single dose of propafenone and a combination of Valsalva test with propafenone in pregnant women in the first trimester with POAVRT.

Data obtained from the study (Table 1) show that during the Valsalva test in patients with POAVRT in the first trimester of pregnancy, there is a decrease in a heart rate by $18.1 \%(\mathrm{p}<0.05)$, points of Wenckebach - by $16.5 \%(\mathrm{p}<0.05)$ and time of a discrete conduction by $24.3 \%(\mathrm{p}<0.01)$. There is also a reduction in a ratio of St2-R2 max/St1-R1 min - by $16.9 \%(\mathrm{p}<0.05)$ and St2-R2/ERP of AV node by $29.4 \%(\mathrm{p}<0.001)$. The increase in the ERP of AV node was by $20.1 \%$ ( $<<0.05)$, ERP of left atrium (LA) was by $20.3 \%(p<0.05)$. The increase in the upper window of tachycardia by $19.3 \%(\mathrm{p}<0.05)$ and the lower windows of the tachycardia by $31.1 \%(\mathrm{p}<0.01)$ has led to the reduction of tachycardia zone by $22.1 \%(\mathrm{p}<0.01)$.

Patients with POAVRT in the first trimester of pregnancy during the Valsalva test 10 indicators from the main $16 \mathrm{EPh}$ indicators (which were involved in relieving of POAVRT and maintaining sinus rhythm) have statistically significantly changed (62.5\%). 
Table 1: EPh parameters of the heart during the Valsalva test, after a single dose of propafenone and a combination of Valsalva test with propafenone in pregnant women in the first trimester with POAVRT $(\mathrm{M} \pm \mathrm{m})$

\begin{tabular}{|c|c|c|c|c|c|}
\hline \multirow[t]{3}{*}{ EPh indicators of POAVRT } & \multirow{3}{*}{$\begin{array}{l}\begin{array}{l}\text { Before } \\
\text { pregnancy }\end{array} \\
1\end{array}$} & \multicolumn{4}{|c|}{ The first trimester of pregnancy $(n=28)$} \\
\hline & & Outcome & Valsalva test & Propafenone & $\begin{array}{l}\text { Valsalva } \\
\text { test+propafenone }\end{array}$ \\
\hline & & 2 & 3 & 4 & 5 \\
\hline HR, min & $62.8 \pm 3.4$ & $\begin{array}{l}74.5 \pm 4.7 \\
\mathrm{p}_{1-2}<0.05^{*}\end{array}$ & $\begin{array}{l}61.0 \pm 3.9 \\
\mathrm{p}_{1-3}>0.05 \\
\mathrm{p}_{2-3}<0.05^{*}\end{array}$ & $\begin{array}{l}64.8 \pm 4.1 \\
\mathrm{p}_{1-4}>0.05 \\
\mathrm{p}_{2-4}>0.05 \\
\mathrm{p}_{3-4}>0.05\end{array}$ & $\begin{array}{l}63.7 \pm 3.8 \\
p_{1-5}>0.05 \\
p_{2-5}>0.05 \\
p_{4-5}>0.05\end{array}$ \\
\hline $\mathrm{P}, \mathrm{ms}$ & $86.4 \pm 5.5$ & $\begin{array}{l}89.2 \pm 5.4 \\
p_{1-2}>0.05\end{array}$ & $\begin{array}{l}85.3 \pm 4.8 \\
\mathrm{p}_{1-3}>0.05 \\
\mathrm{p}_{2-3}>0.05\end{array}$ & $\begin{array}{l}92.5 \pm 5.5 \\
\mathrm{p}_{1-4}>0.05 \\
\mathrm{p}_{2-4}>0.05 \\
\mathrm{p}_{3-4}>0.05\end{array}$ & $\begin{array}{l}93.6 \pm 5.2 \\
\mathrm{p}_{1-5}>0.05 \\
\mathrm{p}_{2-5}>0.05 \\
\mathrm{p}_{4-5}>0.05\end{array}$ \\
\hline $\mathrm{P}-\mathrm{Q}, \mathrm{ms}$ & $154.3 \pm 9.8$ & $\begin{array}{l}155.8 \pm 9.7 \\
p_{1-2}>0.05\end{array}$ & $\begin{array}{l}157.6 \pm 9.5 \\
\mathrm{p}_{1-3}>0.05 \\
\mathrm{p}_{2-3}>0.05\end{array}$ & $\begin{array}{l}158.2 \pm 9.5 \\
\mathrm{p}_{1-4}>0.05 \\
\mathrm{p}_{2-4}>0.05 \\
\mathrm{p}_{3-4}>0.05\end{array}$ & $\begin{array}{l}160.3 \pm 10.0 \\
\mathrm{p}_{1-5}>0.05 \\
\mathrm{p}_{2-5}>0.05 \\
\mathrm{p}_{4-5}>0.05\end{array}$ \\
\hline QRS, ms & $92.5 \pm 5.9$ & $\begin{array}{l}93.8 \pm 5.9 \\
\mathrm{p}_{1-2}>0.05\end{array}$ & $\begin{array}{l}95.8 \pm 5.6 \\
\mathrm{p}_{1-3}>0.05 \\
\mathrm{p}_{2-3}>0.05\end{array}$ & $\begin{array}{l}96.5 \pm 5.8 \\
\mathrm{p}_{1-4}>0.05 \\
\mathrm{p}_{2-4}>0.05 \\
\mathrm{p}_{2}>0.05\end{array}$ & $\begin{array}{l}97.4 \pm 5.4 \\
\mathrm{p}_{1-5}>0.05 \\
\mathrm{p}_{2-5}>0.05 \\
\mathrm{p}>0.05\end{array}$ \\
\hline QT, ms & $365.8 \pm 23.1$ & $\begin{array}{l}360.4 \pm 21.9 \\
p_{1-2}>0.05\end{array}$ & $\begin{array}{l}363.8 \pm 23.1 \\
\mathrm{p}_{1-3}>0.05 \\
\mathrm{p}_{2-3}>0.05\end{array}$ & $\begin{array}{l}366.8 \pm 23.3 \\
\mathrm{p}_{1-4}>0.05 \\
\mathrm{p}_{2-4}>0.05 \\
\mathrm{p}_{3-4}>0.05\end{array}$ & $\begin{array}{l}368.6 \pm 23.3 \\
\mathrm{p}_{1-5}>0.05 \\
\mathrm{p}_{2-5}>0.05 \\
\mathrm{p}_{4-5}>0.05\end{array}$ \\
\hline Corrected time of sinus node function recovery, ms & $324.6 \pm 20.8$ & $\begin{array}{l}336.4 \pm 21.2 \\
p_{1-2}>0.05\end{array}$ & $\begin{array}{l}343.2 \pm 21.7 \\
\mathrm{p}_{1-3}>0.05 \\
\mathrm{p}_{2-3}>0.05\end{array}$ & $\begin{array}{l}349.8 \pm 22.2 \\
\mathrm{p}_{1-4}>0.05 \\
\mathrm{p}_{2-4}>0.05 \\
\mathrm{p}_{2}>0.05\end{array}$ & $\begin{array}{l}357.4 \pm 22.6 \\
\mathrm{p}_{1-5}>0.05 \\
\mathrm{p}_{2-5}>0.05 \\
\mathrm{p}>0.05\end{array}$ \\
\hline ERP of AV node, ms & $372.3 \pm 23.9$ & $\begin{array}{l}309.6 \pm 20.0 \\
\mathrm{p}_{1-2}<0.05^{*}\end{array}$ & $\begin{array}{l}371.8 \pm 22.6 \\
\mathrm{p}_{1-3}>0.05 \\
\mathrm{p}_{2-3}<0.05^{*}\end{array}$ & $\begin{array}{l}378.2 \pm 23.1 \\
\mathrm{p}_{1-4}>0.05 \\
\mathrm{p}_{2-4}<0.05^{*} \\
\mathrm{p}^{2}>0.05\end{array}$ & $\begin{array}{l}374.5 \pm 23.6 \\
\mathrm{p}_{1-5}>0.05 \\
\mathrm{p}_{2-5}<0.05^{*}\end{array}$ \\
\hline Time of a discrete holding, ms & $58.6 \pm 3.5$ & $\begin{array}{l}88.2 \pm 57 \\
p_{1-2}<0.001^{*}\end{array}$ & $\begin{array}{l}66.8 \pm 4.2 \\
\mathrm{p}_{1-3}>0.05 \\
\mathrm{p}_{2-3}<0.01^{*}\end{array}$ & $\begin{array}{l}63.2 \pm 4.0 \\
\mathrm{p}_{1-4}>0.05 \\
\mathrm{p}_{2-4}<0.001^{*} \\
\mathrm{p}_{3-4}>0.05\end{array}$ & $\begin{array}{l}\mathrm{p}_{4-5}>0.05 \\
51.5 \pm 3.2 \\
\mathrm{p}_{1-5}>0.05 \\
\mathrm{p}_{2-5}<0.001^{*} \\
\mathrm{p}_{4-5}<0.05^{*}\end{array}$ \\
\hline Wenckebach point, pulse/min & $156.8 \pm 9.3$ & $\begin{array}{l}158.4 \pm 9.9 \\
p_{1-2}>0.05\end{array}$ & $\begin{array}{l}132.3 \pm 8.1 \\
\mathrm{p}_{1-3}>0.05 \\
\mathrm{p}_{2-3}<0.05^{*}\end{array}$ & $\begin{array}{l}135.5 \pm 8.6 \\
\mathrm{p}_{1-4}>0.05 \\
\mathrm{p}_{2-4}>0.05 \\
\mathrm{p}_{2}>0.05\end{array}$ & $\begin{array}{l}134.8 \pm 9.1 \\
\mathrm{p}_{1-5}>0.05 \\
\mathrm{p}_{2-5}>0.05 \\
\mathrm{p}^{4-5}>0.05\end{array}$ \\
\hline The top window of tachycardia, ms & $366.8 \pm 23.0$ & $\begin{array}{l}306.4 \pm 19.6 \\
p_{1-2}<0.05^{*}\end{array}$ & $\begin{array}{l}365.4 \pm 21.7 \\
\mathrm{p}_{1-3}>0.05 \\
\mathrm{p}_{2-3}<0.05^{*}\end{array}$ & $\begin{array}{l}367.8 \pm 21.9 \\
\mathrm{p}_{1-4}>0.05 \\
\mathrm{p}_{2-4}<0.05^{*}\end{array}$ & $\begin{array}{l}371.8 \pm 23.5 \\
\mathrm{p}_{1-5}>0.05 \\
\mathrm{p}_{2-5}<0.05^{*}\end{array}$ \\
\hline The lower window of tachycardia, ms & $294.7 \pm 18.0$ & $\begin{array}{l}217.8 \pm 13.9 \\
\mathrm{p}_{1-2}<0.001^{*}\end{array}$ & $\begin{array}{l}285.6 \pm 17.6 \\
\mathrm{p}_{1-3}>0.05 \\
\mathrm{p}_{2-3}<0.01^{*}\end{array}$ & $\begin{array}{l}\mathrm{p}_{3-4}>0.05 \\
283.1 \pm 18.1 \\
\mathrm{p}_{1-4}>0.05 \\
\mathrm{p}_{2-4}<0.01^{*} \\
\mathrm{p}_{3-4}>0.05\end{array}$ & $\begin{array}{l}\mathrm{p}_{4-5}>0.05 \\
292.7 \pm 18.2 \\
\mathrm{p}_{1-5}>0.05 \\
\mathrm{p}_{2-5}<0.01^{*} \\
\mathrm{p}_{4-5}>0.05\end{array}$ \\
\hline Area of tachycardia, ms & $63.6 \pm 4.0$ & $\begin{array}{l}96.7 \pm 6.1 \\
\mathrm{p}_{1-2}<0.001^{*}\end{array}$ & $\begin{array}{l}75.3 \pm 4.6 \\
\mathrm{p}_{1-3}>0.05 \\
\mathrm{p}_{2-3}<0.01 *\end{array}$ & $\begin{array}{l}74.7 \pm 4.9 \\
\mathrm{p}_{1-4}>0.05 \\
\mathrm{p}_{2-4}<0.01^{*} \\
\mathrm{p}_{3-4}>0.05\end{array}$ & $\begin{array}{l}64.2 \pm 4.0 \\
\mathrm{p}_{1-5}>0.05 \\
\mathrm{p}_{2-5}<0.001^{*} \\
\mathrm{p}_{4-5}>0.05\end{array}$ \\
\hline RR of tachycardia, mc & $372.5 \pm 23.5$ & $\begin{array}{l}374.8 \pm 23.8 \\
\mathrm{p}_{1-2}>0.05\end{array}$ & $\begin{array}{l}350.7 \pm 22.4 \\
\mathrm{p}_{1-3}>0.05 \\
\mathrm{p}_{2-3}>0.05\end{array}$ & $\begin{array}{l}358.7 \pm 22.9 \\
\mathrm{p}_{1-4}>0.05 \\
\mathrm{p}_{2-4}>0.05 \\
\mathrm{p}_{3-4}>0.05\end{array}$ & $\begin{array}{l}376.3 \pm 23.8 \\
\mathrm{p}_{1-5}>0.05 \\
\mathrm{p}_{2-5}>0.05 \\
\mathrm{p}_{4-5}>0.05\end{array}$ \\
\hline VA of tachycardia, mc & $116.2 \pm 7.3$ & $\begin{array}{l}116.9 \pm 7.4 \\
p_{1-2}>0.05\end{array}$ & $\begin{array}{l}115.4 \pm 7.2 \\
\mathrm{p}_{1-3}>0.05 \\
\mathrm{p}_{2-3}>0.05\end{array}$ & $\begin{array}{l}118.7 \pm 7.6 \\
\mathrm{p}_{1-4}>0.05 \\
\mathrm{p}_{2-4}>0.05 \\
\mathrm{p}_{3-4}>0.05\end{array}$ & $\begin{array}{l}119.4 \pm 7.6 \\
\mathrm{p}_{1-5}>0.05 \\
\mathrm{p}_{2-5}>0.05 \\
\mathrm{p}_{4-5}>0.05\end{array}$ \\
\hline $\mathrm{AV}$ of tachycardia, ms & $253.6 \pm 16.3$ & $\begin{array}{l}257.4 \pm 16.7 \\
\mathrm{p}_{1-2}>0.05\end{array}$ & $\begin{array}{l}254.9 \pm 16.1 \\
\mathrm{p}_{1-3}>0.05 \\
\mathrm{p}_{2-3}>0.05\end{array}$ & $\begin{array}{l}258.3 \pm 16.4 \\
\mathrm{p}_{1-4}>0.05 \\
\mathrm{p}_{2-4}>0.05 \\
\mathrm{p}_{3-4}>0.05\end{array}$ & $\begin{array}{l}260.5 \pm 16.7 \\
\mathrm{p}_{1-5}>0.05 \\
\mathrm{p}_{2-5}>0.05 \\
\mathrm{p}_{4-5}>0.05\end{array}$ \\
\hline
\end{tabular}


Table 1: (Continued)

\begin{tabular}{|c|c|c|c|c|c|}
\hline \multirow[t]{3}{*}{ EPh indicators of POAVRT } & \multirow{2}{*}{$\begin{array}{l}\text { Before } \\
\text { pregnancy }\end{array}$} & \multicolumn{4}{|c|}{ The first trimester of pregnancy $(n=28)$} \\
\hline & & Outcome & Valsalva test & Propafenone & $\begin{array}{l}\text { Valsalva } \\
\text { test+propafenone }\end{array}$ \\
\hline & 1 & 2 & 3 & 4 & 5 \\
\hline ERP of LA, ms & $286.4 \pm 18.0$ & $\begin{array}{l}209.7 \pm 13.3 \\
\mathrm{p}_{1-2}<0.001^{*}\end{array}$ & $\begin{array}{l}251.7 \pm 15.0 \\
\mathrm{p}_{1-3}>0.05 \\
\mathrm{p}_{2-3}<0.05^{*}\end{array}$ & $\begin{array}{l}252.5 \pm 15.5 \\
\mathrm{p}_{1-4}>0.05 \\
\mathrm{p}_{2-4}<0.05^{*} \\
\mathrm{p}_{3-4}>0.05\end{array}$ & $\begin{array}{l}279.2 \pm 17.7 \\
\mathrm{p}_{1-5}>0.05 \\
\mathrm{p}_{2-5}<0.01^{*} \\
\mathrm{p}_{4-5}>0.05\end{array}$ \\
\hline St1-R1 min, ms & $153.6 \pm 9.0$ & $\begin{array}{l}138.7 \pm 8.5 \\
\mathrm{p}_{1-2}>0.05\end{array}$ & $\begin{array}{l}150.1 \pm 9.7 \\
\mathrm{p}_{1-3}>0.05 \\
\mathrm{p}_{2-3}>0.05\end{array}$ & $\begin{array}{l}155.2 \pm 9.9 \\
\mathrm{p}_{1-4}>0.05 \\
\mathrm{p}_{2-4}>0.05 \\
\mathrm{p}_{2-4}>0.05\end{array}$ & $\begin{array}{l}170.8 \pm 7.8 \\
\mathrm{p}_{1-5}>0.05 \\
\mathrm{p}_{2-5}<0.01^{*} \\
\mathrm{p}_{4-5}>0.05\end{array}$ \\
\hline St2-R2 max, ms & $228.7 \pm 10.4$ & $\begin{array}{l}256.4 \pm 15.1 \\
p_{1-2}>0.05\end{array}$ & $\begin{array}{l}230.5 \pm 14.6 \\
p_{1-3}>0.05 \\
p_{2-3}>0.05\end{array}$ & $\begin{array}{l}234.2 \pm 195.3 \\
\mathrm{p}_{1-4}>0.05 \\
\mathrm{p}_{2-4}>0.05 \\
\mathrm{p}_{3-4}>0.05\end{array}$ & $\begin{array}{l}212.6 \pm 15.0 \\
\mathrm{p}_{1-5}>0.05 \\
\mathrm{p}_{2-5}<0.05^{*} \\
\mathrm{p}_{4-5}>0.05\end{array}$ \\
\hline St2-R2 growth, ms & $38.6 \pm 2.4$ & $\begin{array}{l}41.5 \pm 2.6 \\
p_{1-2}>0.05\end{array}$ & $\begin{array}{l}37.6 \pm 2.4 \\
\mathrm{p}_{1-3}>0.05 \\
\mathrm{p}_{2-3}>0.05\end{array}$ & $\begin{array}{l}36.8 \pm 2.1 \\
\mathrm{p}_{1-4}>0.05 \\
\mathrm{p}_{2-4}>0.05 \\
\mathrm{p}_{3-4}>0.05\end{array}$ & $\begin{array}{l}34.6 \pm 2.1 \\
\mathrm{p}_{1-5}>0.05 \\
\mathrm{p}_{2-5}<0.05^{*} \\
\mathrm{p}_{-5}>0.05\end{array}$ \\
\hline $\begin{array}{l}\text { St2-R2 max/ } \\
\text { St1-R1 min }\end{array}$ & $1.5 \pm 0.1$ & $\begin{array}{l}1.85 \pm 0.11 \\
\mathrm{p}_{1-2}<0.05^{*}\end{array}$ & $\begin{array}{l}1.54 \pm 0.10 \\
\mathrm{p}_{1-3}>0.05 \\
\mathrm{p}_{2-3}<0.05^{*}\end{array}$ & $\begin{array}{l}1.51 \pm 0.08 \\
\mathrm{p}_{1-4}>0.05 \\
\mathrm{p}_{2-4}<0.05^{*} \\
\mathrm{p}_{3-4}>0.05\end{array}$ & $\begin{array}{l}1.24 \pm 0.09 \\
\mathrm{p}_{1-5}>0.05 \\
\mathrm{p}_{2-5}<0.01^{*} \\
\mathrm{p}_{4-5}<0.05^{*}\end{array}$ \\
\hline St2-R2/ERP of AV node & $0.8 \pm 0.05$ & $\begin{array}{l}1.19 \pm 0.07 \\
\mathrm{p}_{1-2}<0.001^{*}\end{array}$ & $\begin{array}{l}0.84 \pm 0.06 \\
\mathrm{p}_{1-3}>0.05 \\
\mathrm{p}_{2-3}<0.001^{*}\end{array}$ & $\begin{array}{l}0.81 \pm 0.05 \\
\mathrm{p}_{1-4}>0.05 \\
\mathrm{p}_{2-4}<0.001^{*} \\
\mathrm{p}_{3-4}>0.05\end{array}$ & $\begin{array}{l}0.62 \pm 0.05 \\
\mathrm{p}_{1-5}<0.05^{*} \\
\mathrm{p}_{2-5}<0.001^{*} \\
\mathrm{p}_{4-5}<0.05^{*}\end{array}$ \\
\hline
\end{tabular}

*Statistically significant indicators. ERP: Effective refractory period, AV: Atrioventricular, LA: Left atrium, VA: Ventriculoatrial, HR: Heart rate, EPh: Electrophysiological, POVART: Paroxysms of orthodromic atrioventricular tachycardia

Among the 28 patients with POAVRT in the first trimester during a Valsalva test was achieved a relief of the arrhythmia by blocking in the anterograde direction through the AV node in 11 women (39.3\%), in $3(10.7 \%)$ - in retrograde, in $1(3.6 \%)$ - in anterograde and retrograde, in $13(46.4 \%)$ a relief failed.

In a numerous EPh studies $[1,3,10,11]$ of antiarrhythmic drugs action at the cellular level, it is proved that there is no single antiarrhythmic drug, which has only one single point of application at the level of the cell membrane. Antiarrhythmic drugs which mainly affect Na channels (propafenone) simultaneously can modify K- and Ca-channels [2]. Amiodarone, in addition to the predominant influence on K-channels, also simultaneously modifies $\mathrm{Na}$ - and Ca-channels and meanwhile has $\alpha$ - and $\beta$-blocking action [2]. At the same time, these studies have not concerned the EPh assessment of vagal tests. As can be seen from the obtained data, vagal tests and antiarrhythmic drugs have multiple points of application $[6,7,9]$. A relief of the paroxysm through the blockade of anterograde and retrograde pathways proves this.

Side effects of Valsalva test were observed in 1 (3.6\%) patient.

The conducted correlation analysis in the first trimester showed (Fig. 1) that between the dynamics of EPh indicators during the Valsalva test and the frequency of spontaneous seizures in a year, there is a strong inverse relationship $(\mathrm{r}=-0.9303, \mathrm{n}=28, \mathrm{p}<0.01)$.

After a single dose of propafenone in patients in the first trimester of pregnancy with POAVRT, it was revealed a decrease in the discrete holding time - by $39.6 \%(\mathrm{p}<0.001)$, ratio St2-R2 max/St1-R1 min - by $22.5 \%(\mathrm{p}<0.05)$, and St2-R2/ERP of AV node by $46.9 \%(\mathrm{p}<0.001)$ and was established the increase in the ERP of AV node by $18.1 \%(p<0.05)$, ERP of LA - by $17.0 \%(\mathrm{p}<0.05)$. The increase in the upper window of tachycardia by $16.7 \%(\mathrm{p}<0.05)$ and the lower window of tachycardia by $23.1 \%(\mathrm{p}<0.01)$ has led to the narrowing of tachycardia by $29.5 \%$ $(\mathrm{p}<0.01)$.

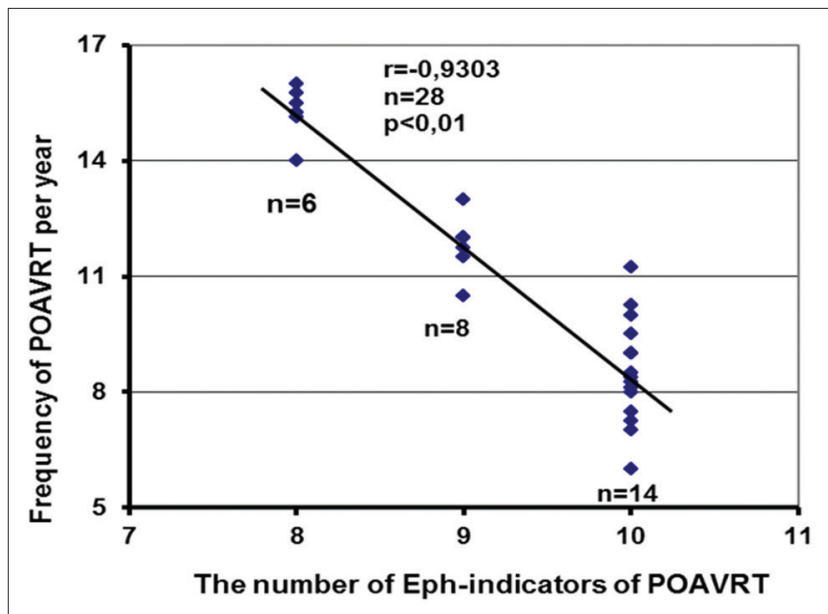

Fig. 1: The effect of Valsalva test on a correlation between electrophysiological - indicators of POAVRT and a frequency of paroxysms per year in the first trimester

After a single dose of propafenone in patients in the first trimester of pregnancy with POAVRT, among 16 ECG and EPh indicators, 8 of them were statistically significantly changed $(50.0 \%)$. These 8 indicators were involved in relieving of POAVRT and in maintaining of a sinus rhythm.

Among the 28 patients in the first trimester with POAVRT, a relief of arrhythmia with a singular propafenone use has been achieved by the blockade of conduction in 18 women $(64.8 \%)$ in the anterograde direction through the AV node, in 5 women $(17.9 \%)$ in the retrograde direction, in $2(7.1 \%)$ - in the anterograde and retrograde, in $3-(10.7 \%)$ the blockade failed. Side effects from a single dose of propafenone were in $2(7.1 \%)$ patients. 


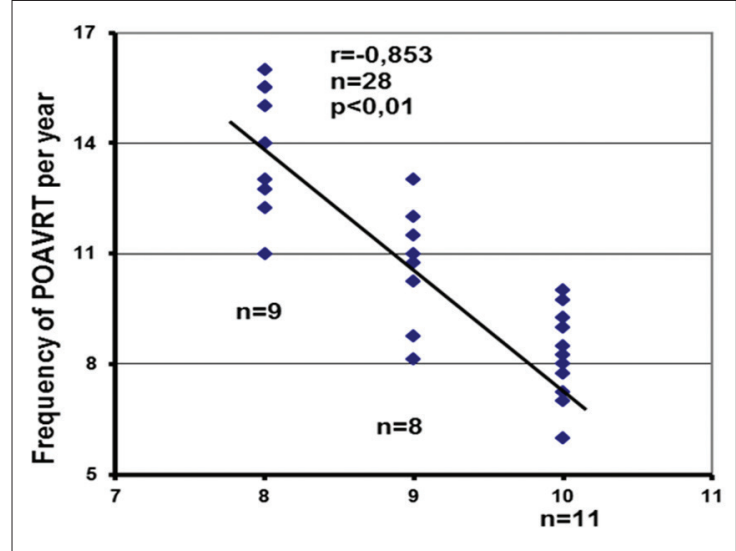

The number of Eph-indicators of POAVRT

Fig. 2: The effect of propafenone on a correlation between electrophysiological performance of POAVRT and a frequency of paroxysms per year in the first trimester

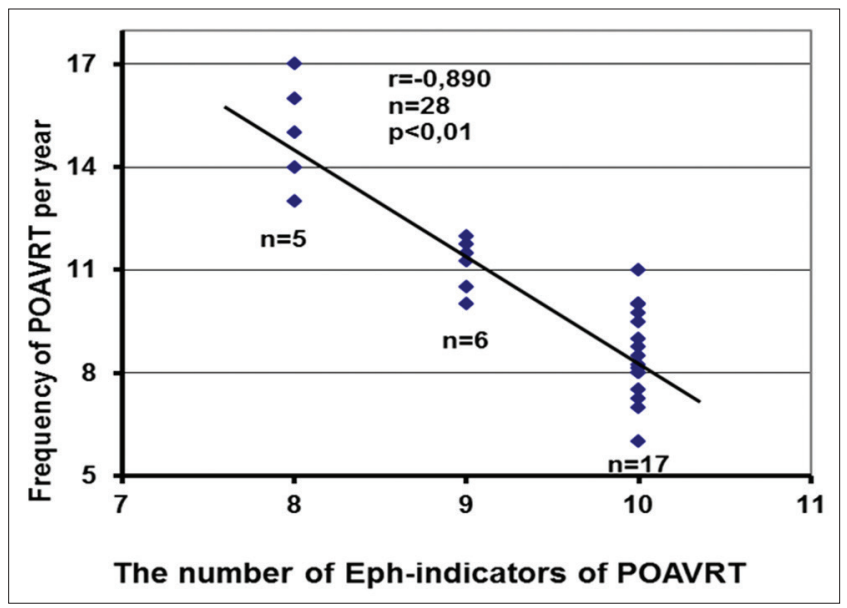

Fig. 3: The effect of a combination of Valsalva test with propafenone on a correlation between electrophysiological indicators of POAVRT and a frequency of paroxysms per year in the first trimester

The conducted correlation analysis showed (Fig. 2) that in women, in the first trimester, who were taking propafenone had inverse relationships between the EPh indicators responsible for the maintenance of sinus rhythm and the frequency of spontaneous seizures in a year $(r=-0.8530$, $\mathrm{n}=28, \mathrm{p}<0.01$ ).

In our opinion, the evaluation of influencing the EPh indicators of POAVRT in combination of Valsalva test with propafenone is of a particular interest.

A combined use of propafenone during conduction of Valsalva test was revealed a reduction of the discrete time by $71.3 \%(\mathrm{p}<0.001)$, ratio St2-R2 max/St1-R1 min - by 48.5\% ( $<<0.001)$, and St2-R2/ERP of AV node - by $92.0 \%(\mathrm{p}<0.001)$. The increase in the ERP of AV node was by $17.3 \%(\mathrm{p}<0.05)$, ERP of LA - by $24.9 \%(\mathrm{p}<0.01)$. A slight increase in the upper window of tachycardia by $17.6 \%(\mathrm{p}<0.05)$ and a marked increase in the bottom window of tachycardia by $25.6 \%(\mathrm{p}<0.01)$ have led to the reduction of tachycardia zone by $50.6 \%(\mathrm{p}<0.001)$.

In contrast to the Valsalva test alone and propafenone alone the combined use of Valsalva test with propafenone caused an increase in St1-R1 min by $18.8 \%(\mathrm{p}<0.01)$, a reduction of the St2-R2 max by $20.6 \%$ $(\mathrm{p}<0.05)$ and St2-R2 increase by $195 . \%(\mathrm{p}<0.05)$. As can be seen from the obtained data, compare a single use of propafenone with a combined use of Valsalva test with propafenone, we can see the additional time reduction of the discrete holding - by $18.5 \%(\mathrm{p}<0.05)$, the ratio St2-R2 max/St1-R1 min - by $17.5 \%(\mathrm{p}<0.05)$ and St2-R2/ERP of AV node by $23.5 \%(\mathrm{p}<0.05)$.

Among the $16 \mathrm{EPh}$ indicators statistically significantly have changed $11(68.8 \%)$. Among the 28 patients in the first trimester with POAVRT as the result of the combined use of Valsalva test with propafenone, a relief of the arrhythmia by blocking of a conduction in the anterograde direction through the AV node was achieved in 16 patients (57.1\%), in $7(25.0 \%)$ - by the retrograde, in $4(14.3 \%)$ - by the anterograde and retrograde, in $1(3.6 \%)$ - the blocking failed. The adverse events in a concomitant use of Valsalva test with propafenone were observed in 3 patients $(10.7 \%)$

The conducted correlation analysis showed (Fig. 3) that in the first trimester, the combined use of Valsalva test with propafenone demonstrates a strong inverse relationship between the EPh indicators responsible for the maintenance of a sinus rhythm and the frequency of spontaneous seizures in a year $(r=-0.8901, n=28, p<0.01)$.

It is known that the dynamics of above-mentioned EPh indicators of POAVRT evidence of the relief efficacy and prophylactic efficacy of Valsalva test and propafenone [4]. Based on the obtained data, it is evident that in patients in the first trimester of pregnancy with POAVRT, the arrhythmia relief should begin with the Valsalva test; however, in the absence of an effect, we can go to the combined use of Valsalva test with propafenone. It should also be noted that the combined application of Valsalva test with propafenone is not only increasing the number of analyzed parameters but also potentiating the EPh effect.

\section{CONCLUSION}

In patients with paroxysms of reciprocal $\mathrm{AV}$ orthodrome tachycardia in early stages of a gestation as a result of the analysis of $16 \mathrm{EPh}$ indicators, it was established that 10 of them $(62.5 \%)$ have changed significantly during carrying out of a Valsalva test, after a single dose of propafenone $-8(50.0 \%)$, in a combined use of Valsalva test with propafenone $-11(68.8 \%)$. It is revealed that the Valsalva test, propafenone, and the combination of Valsalva test with propafenone implement antiarrhythmic effect through anterograde and retrograde link of circulation of excitation. For the first time, it was established that in pregnant patients, the Valsalva test has an impact on the retrograde part of circulation of excitation. It is established that between the number of EPh indicators involved in the circulation of excitation and the frequency of spontaneous seizures in a year, there is an inverse relationship. It is proved that in the first trimester of pregnancy, it is necessary to achieve a relief of POAVRT by Valsalva test and in the absence of the effect - by propafenone alone or by a combination of Valsalva test with propafenone.

\section{REFERENCES}

1. Alekseeva LL. Specific Features of Cardiorespiratory Adaptation in Pregnant Women with Low Obstetric Risk: PhD Dissertation in Medicine. Irkutsk; 2004. p. 300.

2. Bernal O, Moro C. Cardiac arrhythmias in women. Rev Esp Cardiol 2006;59:609-18

3. Chandrasekhar S, Cook CR, Collard CD. Cardiac surgery in the parturient. Anesth Analg 2009;108(3):777-85.

4. Dyatlov NE, Rakhmatullov FK, Kuryaeva AM, Burmistrova LF. The relationship between gestation term and the condition of the heart conduction system in symptomatic atrial fibrillation. University proceedings. Volga region. Med Sci 2016;1(37):54-62.

5. Kavitha V, Srinivas B, Kumar MV, Shashikanth P. Assessment of placental oxidative stress parameters in pre-eclamptic and normal pregnant women. Asian J Pharm Clin Res 2016;9(1):70-4

6. Kornacewicz-Jach Z, Peregud-Pogorzelska M. Maternal arrhythmias during pregnancy. Practical review. Przegl Lek 2014;71:177-81.

7. Rakhmatullov FK, Klimova SV, Kuryaeva AM, Dyatlov NE, 
Zinovyeva EG, Burmistrova LF. The influence of pregnancy on the frequency of extrasystoles and paroxysms of atrioventricular nodal reentrant tachycardia. University Proceedings. Volga region. Med Sci 2015;2:103-12.

8. Sleeba SK, Musthafa AK, Dipu KP, Kabeer PA. A case of sudden cardiorespiratory arrest in lateral medullary syndrome. Asian J Pharm Clin Res 2014;7(4):1-2.

9. Yu M, Yi K, Zhou L, Tan X. Pregnancy increases heart rates during paroxysmal supraventricular tachycardia. Can J Cardiol 2015;31:820-5.

10. Rakhmatullov FK. Transesophageal Electrical Stimulation of the Heart and Clinical Electrophysiology of Antiarrhythmic Medications: A Monograph. Penza: Publishing House of Penza State University; 2006. p. 112.

Stryuk RI, Bukhonkina YU, Brytkova YA, Shoikiemova DU, Pavlova LN. Cardiac arrhythmias in pregnancy. Efficient Pharmacother Cardiol Angiol 2008;1:42-5. 